\title{
PW02-035 - A role for thermo-TRP channels in innate immunity?
}

\author{
M Stoffels ${ }^{1,2,3^{*}}$, T Remijn $^{1}$, LM Elders ${ }^{1}$, HD de Koning ${ }^{1,2,3,4}$, JW van der Meer ${ }^{1,2,3}$, A Simon ${ }^{1,2,3}$ \\ From 7th Congress of International Society of Systemic Auto-Inflammatory Diseases (ISSAID) \\ Lausanne, Switerland. 22-26 May 2013
}

\section{Introduction}

Exposure to cold can induce an exaggerated (local and systemic) inflammatory response in a number of rare disorders, including cryopyrin-associated periodic syndrome (CAPS), and idiopathic cold urticaria (CU). Although it is widely recognized that temperature sensing in neurons is mediated by several transient receptor potential (TRP) channels, it is not known how immune cells sense cold temperatures.

\section{Objectives}

In the present study we aimed to explore how inflammatory cells sense cold.

\section{Methods}

qRT-PCR, western blot and immunohistochemistry were used to detect TRP mRNA and protein in several human-derived cell lines, primary cells and skin biopsies. Cytokine concentrations in culture supernatants of stimulation assays were detected by ELISA.

\section{Results}

mRNA of different thermo-TRPs was detected in PBMCs, macrophages and keratinocytes. The 'cool' menthol receptor TRPM8 is differentially expressed in glycosylated form in immune cells, human fibroblast and lymphoblast cell lines. TRPM8 expression was detected in skin biopsies and localized to the keratinocytes and epithelial cells lining blood vessels. No differences in expression were observed between biopsies from healthy controls and CAPS or CU patients. Preincubation of PBMCs with menthol, a TRPM8-agonist, resulted in enhanced interleukin-1 beta (IL-1 $\beta$ ) secretion in response to TLR stimulation.

Department of General Internal Medicine, Radboud University Nijmegen Medical Centre, Netherlands

Full list of author information is available at the end of the article

\section{Conclusion}

TRPM8 is differentially expressed in human immune cells in glycosylated form, indicating active regulation. Ex vivo stimulation of PBMCs with menthol results in an increased inflammatory response to TLR stimuli. We hypothesize that in vivo cold exposure results in a modulated inflammatory response, through activation of temperature sensitive ion channels. This activation is most likely regulated at the post-translational level.

\section{Competing interests}

None declared.

\section{Authors' details}

'Department of General Internal Medicine, Radboud University Nijmegen Medical Centre, Netherlands. ${ }^{2}$ Nijmegen Institute for Infection, Inflammation and Immunity (N4i), Netherlands. ${ }^{3}$ Nijmegen Centre for Molecular Life Sciences (NCMLS), Netherlands. ${ }^{4}$ Department of Dermatology, Radboud University Nijmegen Medical Centre, Nijmegen, Netherlands.

Published: 8 November 2013

doi:10.1186/1546-0096-11-S1-A176

Cite this article as: Stoffels et al:: PW02-035 - A role for thermo-TRP channels in innate immunity? Pediatric Rheumatology 2013 11(Suppl 1): A176.

Submit your next manuscript to BioMed Central and take full advantage of:

- Convenient online submission

- Thorough peer review

- No space constraints or color figure charges

- Immediate publication on acceptance

- Inclusion in PubMed, CAS, Scopus and Google Scholar

- Research which is freely available for redistribution
C Biomed Central

C 2013 Stoffels et al; licensee BioMed Central Ltd. This is an Open Access article distributed under the terms of the Creative Commons Attribution License (http://creativecommons.org/licenses/by/2.0), which permits unrestricted use, distribution, and reproduction in any medium, provided the original work is properly cited. 